\title{
Assessment of the loss of mass, organic substance and combustible elements in the waste biodegradation process
}

\author{
Agnieszka Generowicz, Małgorzata Olek* \\ The Cracow University of Technology, Institute of Thermal Engineering and Air Protection, ul. Warszawska 24, \\ 31-155 Kraków, Poland \\ "corresponding author: e-mail: mmt.olek@gmail.com
}

\begin{abstract}
The paper presents the results of an analysis of the changes of the mass and amounts of organic substances and combustible elements in a biodegradation process. The prepared sample of organic waste constituted the material used for the tests. The composting process was being carried out for 9 weeks in field conditions. The samples for analyses were collected every 7 days. The content of a biodegradable fraction was determined according to the procedure described in the standard of PN - EN 15169: 2007 "Characterization of waste - Determination of loss on ignition in waste, sludge and sediments". Reduction of the mass of the organic waste during the composting process amounted to $35 \%$. A significant content of organic fraction (about $60-70 \%$ after 9 weeks) remains in the composted waste; and the content of combustible elements is reduced (by about $30 \%$.)
\end{abstract}

Keywords: biodegradable fraction, loss on ignition, composting.

\section{INTRODUCTION}

An estimated quantity of biodegradable waste produced in 1995 in Poland amounted to $4.38 \mathrm{mln} \mathrm{Mg}$. The quantity of the produced biodegradable waste in 2004 was by $14 \%$ higher than in 2000 and by $26 \%$ higher in comparison to a base year - 1995. It is estimated that in 2004 about $4 \mathrm{mln} \mathrm{Mg}$ of municipal biodegradable waste was stored, i.e. about $91 \%$ with reference to the quantity of the produced municipal biodegradable waste in a base year of $1995^{2}$.

According to the provisions of the act on waste ${ }^{1}$ till 2010 , the mass of biodegradable waste directed to waste dumps, in relation to the mass of these substances produced in 1995, cannot exceed $75 \%$. A further reduction of the mass of biodegradable waste passed to the waste dumps should take place in subsequent years:

- in $2013-50 \%$ of the mass of biodegradable waste produced in 1995 ,

- in $2020-35 \%$ of the mass of biodegradable waste produced in $1995^{1}$.

Fulfilment of the afore-mentioned requirements means reduction of the quantity of municipal biodegradable waste to the level of $3.29 \mathrm{mln} \mathrm{Mg}$ in 2010 and $2.19 \mathrm{mln} \mathrm{Mg}$ and $1.53 \mathrm{mln} \mathrm{Mg}$ in subsequent threshold years ${ }^{2}$ on a national scale. Therefore it is estimated that the quantity of biodegradable waste submitted to recovery and neutralization (apart form storage) should form at the levels: $2.5 \mathrm{mln}$ $\mathrm{Mg}, 3.5 \mathrm{mln} \mathrm{Mg}$ and $3.6 \mathrm{mln} \mathrm{Mg}$ in subsequent threshold years. Additionally, according to the provisions of ${ }^{3}$ since 01.01.2013 the substances deposited on the waste dumps must fulfil the following criteria:

- total organic carbon (TOC) lower than $5 \% \mathrm{dm}$,

- loss on ignition (LOI) lower than $8 \% \mathrm{dm}$,

- heat of combustion lower than $6 \mathrm{MJ} / \mathrm{kg} \mathrm{dm}{ }^{3}$.

Therefore the reduction of the quantity of biodegradable waste deposited on the waste dumps is one of the most important tasks of waste policy. Existing solutions within the scope of treatment of the waste do not ensure a sufficient level of reduction of its mass ${ }^{4}$.
Considering quantitative limits (waste undergoing biodegradation) and qualitative limits (all types of waste) for the substances directed to the waste dumps since 2013, an initial analysis of the loss of the mass, organic fraction and changes of fuel properties in the waste undergoing biodegradation that was subjected to a composting process was performed. Analogous considerations were performed for a process of thermal dissolution of biodegradable waste.

\section{EXPERIMENTAL PART AND RESULTS}

The experimental material was constituted of two samples covering solely: food waste of plant origin, grass, paper mixed in the ration of 5:1.4:0.4, of the mass of 0.62 $\mathrm{kg}$ and moisture content of $82 \%$ each. The sample was mixed, and then disintegrated to sampling fraction of graining below $5 \mathrm{~mm}$. The prepared fraction was submitted to a composting process in two piles (marked A and B) in field conditions. The tests were being conducted for 9 weeks. Four representative samples of $5 \mathrm{~g}$ each were collected for analysis once a week, at the beginning of every next composting week.

At the beginning of the examination, before the composting process of the material, the samples were collected for which the mass reduction resulted from combustion at the temperatures of $550^{\circ} \mathrm{C}$ and $800^{\circ} \mathrm{C}$ was defined. The materials stored in pile A was monitored, where the loss of the mass during the composting process was determined, with the use of a gravimetric method. The achieved results were presented in Figure 1.

The moisture content, the content of organic fraction and combustible elements were determined in the samples collected from the field B.

The measurement of the moisture content was executed on the basis of the procedure included in the standard ${ }^{5}$. The collected representative samples of the composted material of $5 \mathrm{~g}$ each were dried to the solid mass at the temperature $105^{\circ} \mathrm{C}$. The achieved results were presented in Figure 1.

The content of the organic fraction was determined according to the procedure described in the standard of 


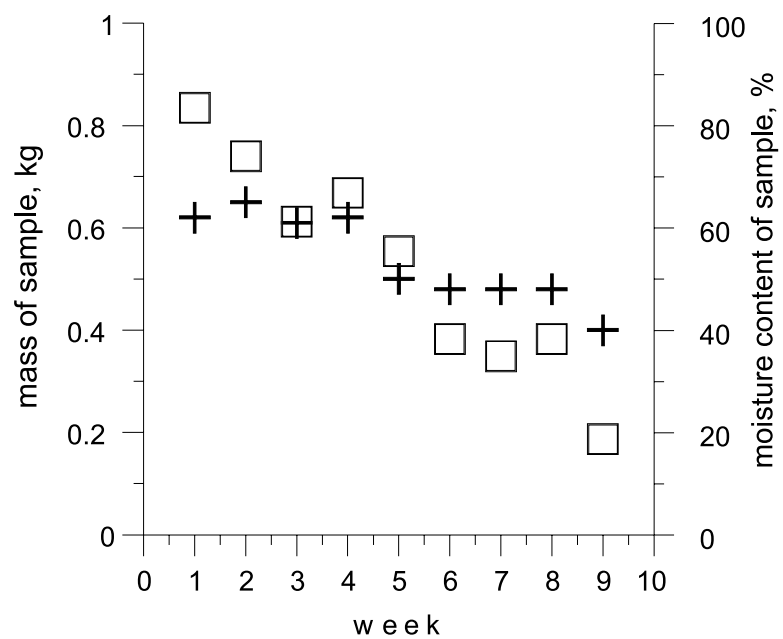

Figure 1. Mass (+) and moisture content ( $\square$ ) of composted waste determined in subsequent weeks of tests

PN - EN 15169:2007 "Characterization of waste - Determination of loss on ignition in waste, sludge and sediments". The loss of organic fraction was determined in the samples dried to the solid mass. The prepared material was submitted to an ignition process at the temperature of $550^{\circ} \mathrm{C}$ for $3 \mathrm{~h}^{6}$. The ignition losses were determined on the basis of the following dependence:

$\mathrm{W}_{\text {LOI }}=100 * \frac{\mathrm{m}_{\mathrm{d}}-\mathrm{m}_{\mathrm{c}}}{\mathrm{m}_{\mathrm{d}}-\mathrm{m}_{\mathrm{a}}}$

where:

$\mathrm{W}_{\text {LOI }}$ - ignition losses, \%

$\mathrm{m}_{\mathrm{a}}$ - mass of the empty pot, $\mathrm{g}$

$\mathrm{m}_{\mathrm{c}}-$ mass of the pot with ignited residue, $\mathrm{g}$

$\mathrm{m}_{\mathrm{d}}$ - mass of the pot with a dry sample (after drying in temperature of $\left.105^{\circ} \mathrm{C}\right), \mathrm{g}$

The exemplary fragmentary results of the measurements of the masses achieved when determining the losses on ignition at the temperature of $550^{\circ} \mathrm{C}$ for 4 samples collected in the first week of tests were presented in Table 1.

The content of the biodegradable substance can be determined on the basis of the results included in Table 1. In this case it is situated within the limits between 80 and $100 \%$ in four samples from one measurement; arithmetic mean amounted to $92 \%$.

Table 1. Fragmentary results of the measurements of mass for an exemplary sample of organic substance, $\mathrm{m}_{\mathrm{b}}$ - mass of pot with analyzed sample (other designation as in the formula)

\begin{tabular}{|c|r|r|r|r|}
\hline Sample No. & $\mathrm{m}_{\mathrm{a}}, \mathrm{g}$ & $\mathrm{m}_{\mathrm{b}}, \mathrm{g}$ & $\mathrm{m}_{\mathrm{c}}, \mathrm{g}$ & \multicolumn{1}{c|}{$\mathrm{m}_{\mathrm{d}} \mathrm{g}$} \\
\hline 1 & 105.45 & 109.26 & 105.45 & 106.16 \\
\hline 2 & 105.86 & 112.32 & 105.86 & 106.85 \\
\hline 3 & 105.29 & 109.73 & 105.48 & 106.20 \\
\hline 4 & 90.37 & 95.68 & 90.45 & 91.07 \\
\hline
\end{tabular}

Losses of the content of biodegradable substance in the composted mass in subsequent weeks of the process were presented in Figure 2. As it is presented in the drawing, the reduction of the mass of biodegradable waste took place from $90 \%$ on average to about $70 \%$ within 9 -week process as a result of the conducted composting process

The samples ignited at the temperature of $550^{\circ} \mathrm{C}$ were submitted to analysis with regard to the content of combustible elements. For this purpose, according to PN $93 / \mathrm{Z} 15008 / 03^{7}$, the analyzed material was put into the

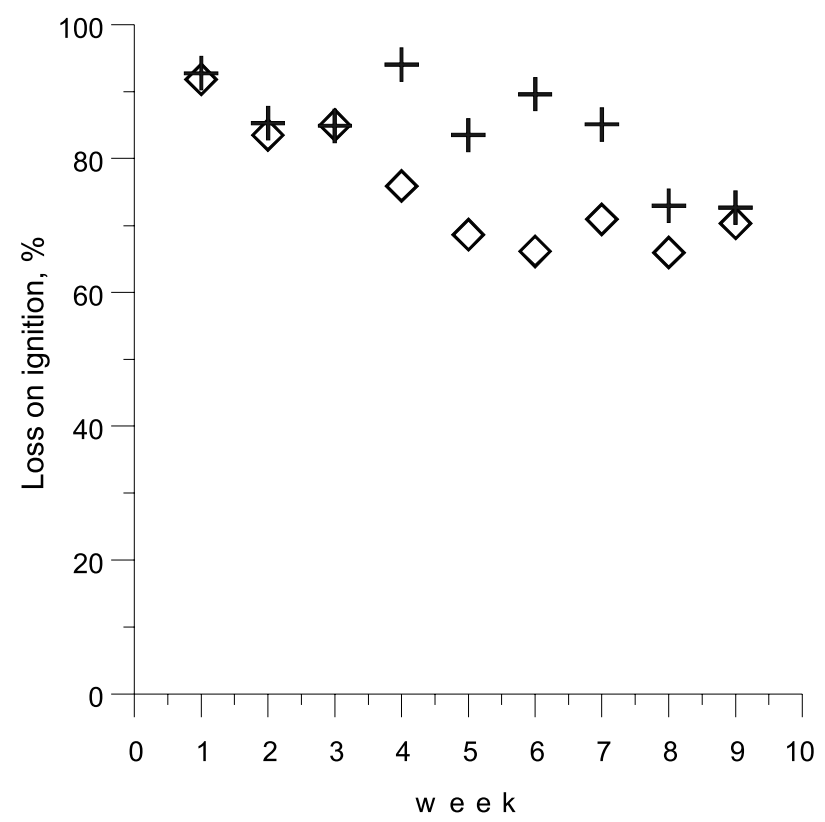

Figure 2. Loss on ignition at the temperature of $550^{\circ} \mathrm{C}(\diamond)$ and at the temperature of $800^{\circ} \mathrm{C}(+)$ in samples collected in subsequent weeks of composting

furnace heated to temperature of $800^{\circ} \mathrm{C}$. The achieved results were presented also in Figure 2. The presented results of the measurements show the content of biodegradable fraction (ignition losses at the temperature of $550^{\circ} \mathrm{C}$ ) and combustible fraction (ignition losses at the temperature of $800^{\circ} \mathrm{C}$ ) in the tested samples of the waste collected in subsequent weeks of the composting process. As it is presented, as the process was being conducted, the content of the organic fraction in wastes was decreasing, and the content of the non-combustible fraction (quantify as the residue after ignition at the temperature of $800^{\circ} \mathrm{C}$ ) was increasing.

Summarizing the results of the tests, it can be noted that the loss of the waste mass was not observed in the pile A after the first 4 weeks of composting. A significant change of the mass was noted in the fifth week of composting, it amounted to $15 \%$ in relation to the mass of the initial material. For the next four weeks no essential changes of the monitored parameter was observed. The loss of mass by next $20 \%$ was observed once again in the ninth week. After 9 weeks of composting we achieved a mass compression of $35 \%$. For comparison, the loss of the mass in the process of thermal dissolution, achieved for the material collected before it was submitted to the composting process, amounted to $99 \%$.

The content of the organic fraction in a substrate submitted to the composting process in pile $\mathrm{B}$, determined by the ignition losses at the temperature of $550^{\circ} \mathrm{C}$, amounted to $92 \%$ on average. After 4 weeks of composting, a significant loss of organic substance, amounting to about $24 \%$ was observed. In subsequent 5 weeks of composting, an average content of organic substance did not undergo significant changes. After 9 weeks of composting, the content of organic fraction in the monitored material amounted to $82 \%$.

Organic waste loses its combustible properties as the composting process is conducted. Within 7 weeks of composting, the content of combustible elements in the analyzed material showed a downward tendency from $93 \%$ 
in the initial material to $85 \%$ in the seventh week of composting. After next two weeks of composting, the content of combustible elements achieve the value of $73 \%$.

For comparison of the results, additionally, a sample of waste undergoing biodegradation, composted in a domestic composter for about one year was submitted to the tests. Composting was conducted in field conditions and it was not a measured process. On the basis of the tests, it was stated that the content of the fraction undergoing biodegradation in the composted mass of waste amounted to $20 \%$, however, the content of combustible elements in the waste amounted only to $23 \%$ of the dry mass. That confirmed the results of the measurements and the conducted tests. During the composting process, the content of waste undergoing biodegradation is decreasing and the content of the non-combustible fractions is increasing.

\section{CONCLUSIONS}

The reduction of the mass of organic waste in the course of the composting process amounts to $35 \%$. After 9 weeks of the process, a significant content of the organic fraction (about $60-70 \%$ ) remains in the composted waste.

In the course of the composting process, a share of the combustible elements undergoes reduction (about 30\% after 9 weeks of the process).

A significant loss of the mass of the processed waste (99\%) and complete elimination of organic fraction takes place in the thermal conversion process. The residues after the thermal conversion of organic waste can be deposited on a waste dump without the consequence of paying the fines for the storage of organic waste.

\section{LITERATURE CITED}

1. The Act on Waste [uniform text: Journal of Laws of 2007, No. 39, item 251, as amended].

2. The National Plan of Waste Management 2010 - Attachment to the Resolution No. 233 of the Council of Ministers of 29 December 2006.

3. The Decree of the Minister of Economy and Labour on the criteria and procedures allowing to storing wastes on landfills of a particular type [Journal of Laws of 2005, No. 186 , item 1553 as amended].

4. Maćków, I., Sebastian, M., Szpadt, R. \& Rajmund, A., Characteristics of organic waste in selected Polish municipalities. W: Waste management in the focus of controversial interests. Proceedings of the 1st BOKU Waste Conference. Vienna, 2005.

5. Standards Association of Poland (2007). Polish standard: Characterization of waste - Calculation of dry matter by determination of dry residue or water content. PN-EN 14346: 2007.

6. Standards Association of Poland (2007). Polish standard: Characterization of waste - Determination of loss on ignition in waste, sludge and sediments. PN - EN 15169: 2007.

7. Standards Association of Poland (1993). Polish standard: Fuel property testing. Determination of the content of combustible. PN - 93/Z15008/03. 